medRxiv preprint doi: https://doi.org/10.1101/2021.10.14.21265004; this version posted October 19, 2021. The copyright holder for this preprint (which was not certified by peer review) is the author/funder, who has granted medRxiv a license to display the preprint in

All rights reserved. No reuse allowed without permission.

\title{
Adapting cleft care protocols in low- and middle-income countries during and after COVID-19: a process-driven review with recommendations
}

\author{
Authors names: \\ Matthew Fell MRCS ${ }^{1,2}$ \\ Michael Goldwasser MD 3,4 \\ B.S Jayanth $M D^{5}$ \\ Rui Manuel Rodrigues Pereira MD ${ }^{6,7}$ \\ Christian Tshisuz Nawej MMED ${ }^{8}$ \\ Rachel Winer BA ${ }^{9}$ \\ Neeti Daftari MA, MSc ${ }^{9}$ \\ Hugh Brewster MEd ${ }^{9}$ \\ Karen Goldschmied SLT ${ }^{10}$
}

\section{Collaborating authors names:}

Fernando Almas $\mathrm{MD}^{11}$

Mekonen Eshete MD ${ }^{12}$

George W. Galiwango MD ${ }^{13}$

Larry H. Hollier Jr. MD ${ }^{14,15}$

Lun-Jou Lo MD ${ }^{16,17}$

Debbie Sell FRCSLT ${ }^{18}$

Amanuel Tafase $\mathrm{MD}^{11}$

Ronald M. Zucker MD ${ }^{19,20}$

\footnotetext{
${ }^{1}$ CLEFT Charity, Chelmsford, United Kingdom

${ }^{2}$ Cleft Collective, University of Bristol, Bristol, United Kingdom

${ }^{3}$ Operation Smile, Virginia Beach, USA

${ }^{4}$ Craniofacial and Surgical Care, University of North Carolina School of Dentistry, Chapel Hill, NC, USA

${ }^{5}$ ABMSS, Bengaluru, India

${ }^{6}$ Faculdade de Medicina da Universidade de Sao Paulo, Sau Paulo, Brazil

${ }^{7}$ Instituto de Medicina Integral Prof Fernando Figueira, Recife, Brazil

${ }^{8}$ Cliniques Universitaires de Lubumbashi, Democratic Republic of Congo

${ }^{9}$ Transforming Faces, Toronto, Canada

${ }^{10}$ Hospital Dr Luis Calvo Mackenna, Santiago de Chile, Chile

${ }^{11}$ Project Harar Ethiopia, Henfield, United Kingdom

${ }^{12}$ Cleft Lip and Palate Program, Yekatit 12 Hospital Medical College, Addis Ababa, Ethiopia

${ }^{13}$ CORSU Rehabilitation Hospital, Kisubi, Uganda

${ }^{14}$ Smile Train Global Medical Advisory Board, New York, USA

${ }^{15}$ Division of Plastic Surgery, Michael E. DeBakey Department of Surgery, Baylor College of Medicine,

Department of Surgery, Texas Children's Hospital, Houston, Texas, USA

${ }^{16}$ Noordhoff Craniofacial Foundation, Taipei, Taiwan

${ }^{17}$ Craniofacial Center, Plastic and Reconstructive Surgery, Chang Gung Memorial Hospital, Taoyuan, Taiwan

${ }^{18}$ Great Ormond Street Hospital for Children, London, United Kingdom
}

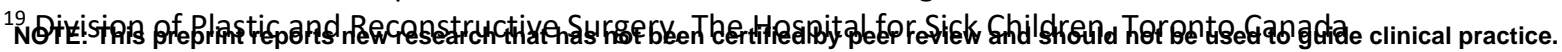

20 The University of Toronto, Toronto, Canada 
medRxiv preprint doi: https://doi.org/10.1101/2021.10.14.21265004; this version posted October 19, 2021. The copyright holder for this preprint (which was not certified by peer review) is the author/funder, who has granted medRxiv a license to display the preprint in All rights reserved. No reuse allowed without permission.

\title{
Corresponding author:
}

\author{
Matthew Fell \\ The Cleft Collective \\ Bristol Dental School \\ University of Bristol \\ Oakfield House \\ Oakfield Grove \\ Bristol \\ BS8 2BN \\ United Kingdom
}

Mobile: 0044 (0)1179505050

Mattfell@doctors.org.uk

Running title: Adapting cleft protocols in LMICs following COVID

Financial support:

MF is supported by the VTCT Foundation for a research fellowship with the Cleft Collective at the University of Bristol

\section{ACKNOWLEDGEMENTS}

The authors would like to thank the Circle of Cleft professionals and the multiple organisations that support it for facilitating this work. 
medRxiv preprint doi: https://doi.org/10.1101/2021.10.14.21265004; this version posted October 19, 2021. The copyright holder for this preprint (which was not certified by peer review) is the author/funder, who has granted medRxiv a license to display the preprint in All rights reserved. No reuse allowed without permission.

Adapting cleft care protocols in low- and middle-income countries during and after COVID-19: a process-driven review with recommendations 
medRxiv preprint doi: https://doi.org/10.1101/2021.10.14.21265004; this version posted October 19, 2021. The copyright holder for this preprint (which was not certified by peer review) is the author/funder, who has granted medRxiv a license to display the preprint in

\begin{abstract}
Objective: A consortium of global cleft professionals, predominantly from low- and middleincome countries, identified adaptions to cleft care protocols during and after COVID as a priority learning area of need.
\end{abstract}

Design: A multidisciplinary international working group met on a videoconferencing platform in a multi-staged process to make consensus recommendations for adaptions to cleft protocols within resource-constrained settings. Feedback was sought from a roundtable discussion forum and global organisations involved in comprehensive cleft care.

Results: Foundational principles were agreed to enable recommendations to be globally relevant and two areas of focus within the specified topic were identified. First the safety aspects of cleft surgery protocols were scrutinised and COVID adaptions, specifically in the pre and peri-operative periods, were highlighted. Second, surgical operations and access to services were prioritized according to their relationship to functional outcomes and timesensitivity. The operations assigned the highest priority were emergent interventions for breathing and nutritional requirements and primary palatoplasty. The cleft services assigned the highest priority were new-born assessments, paediatric support for children with syndromes, management of acute dental or auditory infections and speech pathology intervention.

Conclusions: A collaborative, interdisciplinary and international working group delivered consensus recommendations to assist with the provision of cleft care in low- and middleincome countries. At a time of global cleft care delays due to COVID-19, a united approach 
medRxiv preprint doi: https://doi.org/10.1101/2021.10.14.21265004; this version posted October 19, 2021. The copyright holder for this preprint (which was not certified by peer review) is the author/funder, who has granted medRxiv a license to display the preprint in All rights reserved. No reuse allowed without permission.

amongst global cleft care providers will be advantageous to advocate for children born with cleft lip and palate in resource-constrained settings.

Keywords: comprehensive cleft care, low- and middle-income countries, COVID-19, Circle of Cleft Professionals 
medRxiv preprint doi: https://doi.org/10.1101/2021.10.14.21265004; this version posted October 19, 2021. The copyright holder for this preprint (which was not certified by peer review) is the author/funder, who has granted medRxiv a license to display the preprint in

\section{INTRODUCTION}

Cleft lip and/or palate (CL/P) is the most common craniofacial congenital anomaly, occurring in approximately $1 / 700$ live births worldwide (Mossey et al., 2009). If untreated, $C L / P$ is highly problematic for children and their families as it gives rise to functional difficulties with speech, eating, social interaction and child development. It is well established that the best way to treat a child born with $\mathrm{CL} / \mathrm{P}$ is a multidisciplinary team (MDT) of specialised professionals following a protocol of comprehensive cleft care (Kassam et al., 2020). Unfortunately, global inequalities exist, with provision and access to comprehensive cleft care differing depending on geographical location of birth (Sharratt et al., 2020). Low- and middle-income countries (LMICs) face unique challenges due to the existence of constrained resources (Ma et al., 2020) and data collected in 2014 estimated the backlog of untreated cleft in LMICs to be more than 600,000 cases (Carlson et al., 2016).

On March $11^{\text {th }} 2020$ the World Health Organisation declared COVID-19 to be a global pandemic. This had a major impact on healthcare systems and services were accordingly reprioritised, with emergency and trauma services continuing but many elective procedures being delayed or postponed (American Cleft Palate-Craniofacial Association, 2020a, 2020b; Cleft Development Group, 2020). The pandemic has undoubtedly exacerbated the backlog of healthcare interventions for children born with $\mathrm{CL} / \mathrm{P}$, as they are for the most part regarded as planned elective procedures, although the magnitude of these delays on a global scale is yet to be fully appreciated (Stoehr et al., 2021). Projections using data from 67 LMICs estimated 25,000 fewer cleft operations performed during 2020 compared to 2019 (Vander Burg et al., 2021). In Peru, children born with $\mathrm{CL} / \mathrm{P}$ were having primary reconstructions at a 
medRxiv preprint doi: https://doi.org/10.1101/2021.10.14.21265004; this version posted October 19, 2021. The copyright holder for this preprint (which was not certified by peer review) is the author/funder, who has granted medRxiv a license to display the preprint in

significantly older age during the pandemic when compared to a pre-pandemic cohort, with delays most marked in primary cleft lip and nose reconstruction (Rossell-Perry \& GavinoGutierrez, 2021). Prioritising cleft care in the overcrowded healthcare system when the pandemic ends will be challenging, even in high resource settings (Breugem et al., 2020). LMICs are likely to face additional barriers to reinstating elective cleft services, which may include access to COVID testing, treatment, vaccines, personal protective equipment (PPE) and travel restrictions impacting most upon patients living in remote rural locations (Ramanathan et al., 2021; Stoehr et al., 2021).

The Circle of Cleft Professionals (CoCP) is a coalition of international non-governmental organisations (NGOs), which aims to support healthcare workers around the globe to provide comprehensive cleft care (Circle of Cleft Professionals, 2021a). On September $17^{\text {th }}$ 2020, CoCP facilitated an international virtual conference entitled 'Solutions for Comprehensive Cleft Care: Responding to COVID'. Following the conference, an online CoCP COVID-19 Survey was designed, aiming to identify challenges that cleft professionals face in light of the pandemic, particularly in LMICs, and to identify learning priorities (see supplementary material for copy of survey). The survey was translated into 6 different languages to facilitate broad representation and disseminated internationally online in February 2021 to global cleft professionals through a network alliance of 10 global NGOs. The survey received 175 responses, $74 \%$ of which were from cleft professionals located in one of 40 LMICs (see Supplementary Figure 1). A priority area identified for further learning from the survey was 'adapting COVID-19 cleft care protocols in light of evidence-based research'. 
medRxiv preprint doi: https://doi.org/10.1101/2021.10.14.21265004; this version posted October 19, 2021. The copyright holder for this preprint (which was not certified by peer review) is the author/funder, who has granted medRxiv a license to display the preprint in All rights reserved. No reuse allowed without permission.

A clinical protocol (also known as a plan, pathway or guideline) is a tool to guide evidencebased healthcare (Rotter et al., 2019). A protocol aims to standardise care and has the potential to streamline multidisciplinary clinical practice by detailing steps of management. $\mathrm{CL} / \mathrm{P}$ is associated with a striking diversity of management protocols in common use and furthermore there is a paucity of a scientific evidence to support any of them (de Ladeira and Alonso, 2012; Hardwicke et al., 2017). The reason for this may be the complex, heterogeneous nature of the condition, with multidisciplinary care administered by a range of specialists at different stages of child development (Allori et al., 2017). There are examples of individual cleft centres, such as in Adelaide and Lima, publishing their protocols (Rossell-Perry and Luque-Tipula, 2020; Schnitt et al., 2004) and also nationwide cleft standards, which detail threshold age targets for the completion of primary operations (NHS England, 2018). It is perhaps not surprising that consensus for international standardisation has not been reached for the delivery of cleft care protocols, nor for the assessment of outcomes (Weidler et al., 2021). The World Cleft Coalition, formed from several international NGOs, has published international treatment program standards with a primary focus on the delivery of ethical, safe, accessible and patient-centred care (Kassam et al., 2020). The coalition purposefully did not dwell on protocol technique and timings, due to the well documented controversies in this area, but instead attempted to make balanced recommendations to allow for the levels of resources available locally.

The need to adapt aspects of the cleft protocol during and following COVID-19 has been identified by global partners and is important in the quest towards re-establishing international comprehensive cleft care services. The CoCP platform was used to bring together cleft professionals from diverse locations to consider adaptions to the cleft care 
medRxiv preprint doi: https://doi.org/10.1101/2021.10.14.21265004; this version posted October 19, 2021. The copyright holder for this preprint (which was not certified by peer review) is the author/funder, who has granted medRxiv a license to display the preprint in

protocol by pooling experience and reviewing available evidence. The overall aim was to formulate practical consensus recommendations to help providers in LMICs to deliver comprehensive cleft care protocols during and after COVID-19.

\section{METHODS}

\section{Process overview}

A multi-stage process, designed specifically for this context by CoCP organisers and advisors, is summarised in a flow diagram in Figure 1. The process was centred around the formation of working groups to consider topics highlighted in the CoCP COVID-19 Survey. The application to participate in a working group was disseminated widely through the CoCP membership and beyond. Applicants were placed in one of six working groups based on research interests, fluency in English or Spanish, and in an attempt to ensure diversity of professional context, discipline, geography and NGO affiliation. Working group members were orientated into the process and encouraged to consider their allocated topic area before meeting collectively on three separate occasions over a six-week period in 2021 . The process culminated with a presentation of recommendations at a round table within an international virtual conference, that had free registration and was widely advertised, entitled 'Solutions for Comprehensive Cleft Care: Covid and Beyond' on June $2^{\text {nd }}, 2021$ (Circle of Cleft Professionals, 2021b).

The structure of this report was inspired by the World Cleft Coalition publication (Kassam et al., 2020) as it was considered a rare example of an international collaborative endeavour in 
medRxiv preprint doi: https://doi.org/10.1101/2021.10.14.21265004; this version posted October 19, 2021. The copyright holder for this preprint (which was not certified by peer review) is the author/funder, who has granted medRxiv a license to display the preprint in

global cleft care and the benefit of a similar format for end user interpretation and application was recognised.

\section{Composition of the Working Group}

This working group was composed of seven individuals; six healthcare professionals and one non-healthcare professional in an administrative role (see Table 1). There was representation from seven countries in four continents and inclusion of three speciality areas from the cleft multidisciplinary team. Working group members had a range of experience in the delivery of comprehensive cleft care within their own countries and overseas and were affiliated with a range of global cleft organisations.

\section{Making and testing recommendations}

The working group met virtually on three occasions using a videoconferencing platform. The first session entitled 'exploring' involved open discussion of the assigned topic and highlighting areas within the assigned topic in which to focus. The action plan from the first meeting was to identify available guidance through literature searches in combination with personal experience and organisational contacts. Literature was categorised according to levels of evidence (see supplementary Figure 2) and shared between group members in the interim period to stimulate discussion via email, instant messaging and an online conference platform. The second meeting entitled 'consolidating' involved consideration of the identified evidence and the creation of preliminary consensus recommendations. The final meeting entitled 'Recommending' consisted of reviewing and refining the group consensus recommendations. At the culmination of this process, the working group presented their recommendations at conference round table and attendees were encouraged to comment 
medRxiv preprint doi: https://doi.org/10.1101/2021.10.14.21265004; this version posted October 19, 2021. The copyright holder for this preprint (which was not certified by peer review) is the author/funder, who has granted medRxiv a license to display the preprint in

and provide feedback. The round table enabled a pilot test of the recommendations and an opportunity for feedback from the attending audience. Further feedback was sought from leading cleft professionals allied to the CoCP NGO network. The feedback was used to help understand the global implications of the recommendations and refine them as needed.

\section{RESULTS}

The working group considered the topic area of 'adapting COVID-19 cleft care protocols in light of evidence-based research'. A consensus was reached on foundational principles and recommendations made in two focus areas: first, surgical safety measures within the cleft care protocol and second, prioritisation of surgical procedures and access to cleft care services.

\section{Foundational Principles}

The working group agreed that recommendations for cleft protocol adaptations, supported by a body of identified scientific evidence, could be beneficial to help coordinate and unify the international lobbying of policy makers regarding the need for comprehensive cleft care provision during and after the COVID-19 pandemic in LMICs. The target audience were global cleft care providers in resource-constrained settings, which includes health care professionals and/or management teams at a regional, national or international cleft service delivery level. The aim was to create a document that would be a helpful aid to global lobbying efforts in LMICs, with an appreciation that recommendations could neither be comprehensive nor specific to reflect the needs of each individual healthcare system and setting. 
medRxiv preprint doi: https://doi.org/10.1101/2021.10.14.21265004; this version posted October 19, 2021. The copyright holder for this preprint (which was not certified by peer review) is the author/funder, who has granted medRxiv a license to display the preprint in

Potential pitfalls were recognised with recommendations relating to global cleft care protocols. First, it was clear that cleft protocols would vary enormously in resourceconstrained settings, with influencing factors including the setup of local healthcare services, the socio-economic context, the availability of multidisciplinary care and dependence on external teams for the provision of cleft care. Each nation has its own government, healthcare laws and potential existence of additional crises, such as civil war, which would have a significant impact on the delivery of any healthcare protocol. There was an endeavour to make protocol recommendations that would be broadly applicable, nonjudgemental and evidence-based by referring to relevant literature and guidance. Second, the contentious nature of many aspects of the cleft care protocol was acknowledged, especially with regard to timings, sequences and techniques in use. Prescriptive statements were avoided, with recommendations made instead according to widely accepted principles. The hope was that the recommendations would facilitate the provision of cleft care during and after COVID-19 in LMICs, rather than adding restrictive measures for healthcare providers.

The working group focused upon two areas within the cleft care protocol that were felt to warrant the greatest need; the first focus area was operative safety, and the second was prioritisation of surgical procedures and MDT cleft services.

\section{Focus area 1: Surgical safety adaptions to the cleft care protocol}

The primary focus of any healthcare protocol is to promote the safety of patients, their family and the healthcare providers. Following the inevitable delays in cleft care provision 
medRxiv preprint doi: https://doi.org/10.1101/2021.10.14.21265004; this version posted October 19, 2021. The copyright holder for this preprint (which was not certified by peer review) is the author/funder, who has granted medRxiv a license to display the preprint in All rights reserved. No reuse allowed without permission.

following COVID-19, the reinstatement of cleft services must be done safely and according to the latest available evidence. Many aspects of safety were in place before the pandemic and for the most part, these would continue during or after the pandemic with some notable additions and considerations. Recommendations centred upon suggested additional adaptations to be considered during and after COVID-19 and have been categorised according to the period of operative care (pre, peri and post) as described in Table 2.

Pre-operative safety protocols exist to assess whether the patient is safe to proceed with a procedure and often incorporate a consultation and basic tests. Post-COVID-19, preoperative assessments need to be expanded to judge the risk of the virus causing harm to patients, families and providers. The extent of pre-operative modifications (such as frequency of COVID-19 testing and the need for isolation strategies) can be adapted in response to regional COVID-19 prevalence, which has been classified as low $(<0.5 \%)$, medium (0.5-2\%) and high (>2\%)(Royal College of Paediatrics and Child Health, 2020). Whilst an in-person consultation with the patient, surgeon and anaesthetist remains vital, virtual screening for COVID-19 symptoms can be successfully utilised (Royal College of Paediatrics and Child Health, 2020). COVID-19 testing, performed as close to the time of care as possible, is an important adaptation of the pre-care protocol, whilst recognising the need for flexibility due to access to testing facilities. Establishing vaccination status is important but vaccine availability will likely be a challenge in LMICs due to global inequity and therefore an emphasis on PPE for patient, families and staff may be required (Ma et al., 2020; Stoehr et al., 2021). 
medRxiv preprint doi: https://doi.org/10.1101/2021.10.14.21265004; this version posted October 19, 2021. The copyright holder for this preprint (which was not certified by peer review) is the author/funder, who has granted medRxiv a license to display the preprint in All rights reserved. No reuse allowed without permission.

Peri-operative safety protocols exist to maintain patient well-being whilst under the care of health professionals. Healthcare systems are well accustomed to protocols relating to safety during this period and should have training and equipment in place to deal with adverse events(Operation Smile, 2020; Smile Train, 2018.). The World Health Organisation (WHO) has published guidance on equipment and facilities required to run a safe surgical service (World Health Organisation, 2003). Securing adequate stocks of PPE is an important element of creating a safe working environment but will likely be a challenge amongst other resource shortages in LMICs (Ma et al., 2020). Adaptions are required to factor in the space, facilities and time to address COVID-19 risk reducing precautions such as social distancing and isolation (Cai et al., 2021). Specifically, consent for procedures should detail the risk of contracting COVID-19 during the hospital stay and emphasise the importance of following current COVID-19 guidance (Ramanathan et al., 2021).

Post-operative safety protocols exist to ensure that the surgical care episode was successful and that the patient does not develop complications that require treatment. The decision to follow-up patients in person or remotely is made on the merits and practicalities of both options and has many influencing factors, of which COVID-19 is just one. Irrespective of COVID-19, it remains important that operative outcomes are accurately assessed and recorded and indeed the advances in telemedicine during the COVID-19 pandemic may ultimately make this easier. Arguably, there may not be any specific safety adaptions required in this post-operative phase of the protocol during or following COVID-19 but maintaining levels of follow-up surveillance when resources are restricted may be a challenge. 
medRxiv preprint doi: https://doi.org/10.1101/2021.10.14.21265004; this version posted October 19, 2021. The copyright holder for this preprint (which was not certified by peer review) is the author/funder, who has granted medRxiv a license to display the preprint in

\section{Focus area 2: Prioritisation of surgical procedures and MDT cleft services}

There is a need for prioritisation within the cleft protocol despite each element of comprehensive cleft care having equal importance because some elements are timesensitive and linked to functional outcomes, therefore their delay would lead to irreversible harm(Rossell-Perry and Gavino-Gutierrez, 2021). Prioritisation of care according to clinical urgency has been widely encouraged as a vital part of re-establishing elective services amidst the backlog of untreated cases (Royal College of Paediatrics and Child Health, 2020). Elements of the cleft protocol were prioritised primarily based on time-sensitive functional outcomes, whilst also recognising the importance of aesthetic and psychosocial outcomes.

\section{Prioritisation of surgical procedures}

Surgical emergencies for patients born with $\mathrm{CL} / \mathrm{P}$, such as airway or nutritional compromise, require potentially life-saving surgical interventions and are therefore an obvious priority. The airway can be compromised in Pierre Robin Sequence, primarily due to glossoptosis and emergent surgical procedures to secure the airway, although rare, may be required (Breugem et al., 2016). The utilisation of mandibular distraction osteogenesis for children with micrognathia to improve breathing and eating is more controversial, with long-term outcomes in facial development yet to be determined (Breik et al., 2016), but was prioritised because of it aims to improve vital functions, with the proviso that it formed a part of the agreed local protocol (Ramanathan et al., 2021).

Primary palatoplasty was considered a high priority due to the body of literature identified to demonstrate its relationship with both speech and maxillary growth outcomes (see supplementary table 1 and 2). Evidence suggests the palate needs to be functional when 
medRxiv preprint doi: https://doi.org/10.1101/2021.10.14.21265004; this version posted October 19, 2021. The copyright holder for this preprint (which was not certified by peer review) is the author/funder, who has granted medRxiv a license to display the preprint in All rights reserved. No reuse allowed without permission.

sounds are first learned in order to avoid the development of compensatory speech patterns (Chapman et al., 2008). The optimal primary palatoplasty regime is a source of continued debate (Lohmander et al., 2012; Rohrich and Byrd, 1990) and randomised control trials currently in process aim to define the optimal timing for palatoplasty (Conroy et al., 2021). The SCANDCLEFT trials found that both good and poor functional outcomes can be achieved by a variety of palatoplasty techniques, sequence and timings and concluded that it was probably the operator skill and familiarity with the protocol that was most important (Shaw \& Semb, 2017). Therefore, primary palatoplasty should be performed as a priority according to the accepted techniques, and within the scheduled timeframe, of the local cleft care protocol.

Primary cleft lip repair was categorised as a medium priority as earlier lip repairs have been shown to benefit mother-infant interactions and bonding (Murray et al., 2007). Secondary speech surgery, symptomatic fistulae repair and secondary alveolar bone grafting were medium priorities due to their time-sensitive association with functional outcomes of speech and maxillary growth, although they occur at an older age and with a wider window of opportunity when compared to primary palatoplasty (Breugem et al., 2020). Secondary speech surgery and the repair of symptomatic fistulae may be warranted before the child enters primary education with an aim to achieve normal speech to help optimise educational performance (Sell et al., 2015). Secondary alveolar bone grafting is commonly timed according to the decent of the deciduous canine tooth at approximately 8-12 years of age and aids the functional development of the alveolar arch to provide support for facial structures (Semb, 2012). 
medRxiv preprint doi: https://doi.org/10.1101/2021.10.14.21265004; this version posted October 19, 2021. The copyright holder for this preprint (which was not certified by peer review) is the author/funder, who has granted medRxiv a license to display the preprint in

Orthognathic surgery, secondary rhinoplasty, revisional lip procedures and routine dental procedures were categorised as a lower priority, not to undermine their importance, but because they are not as acutely time sensitive.

\section{Prioritisation of access to cleft care services}

New-born babies with $\mathrm{CL} / \mathrm{P}$ need to be assessed regarding breathing, feeding and hearing and this is a priority, both for the health of the baby and to provide support for parents during this critical neonatal period. Some children with $C L / P$, especially those with syndromes, will require ongoing input from medical professionals with paediatric experience. Acute dental infections or otitis media were prioritised because efficient treatment reduces the likelihood of permanent damage to dentition and hearing(Kuo et al., 2013). Speech pathology intervention was categorised in the highest priority to reflect the importance of speech outcomes and evidence to suggest that speech interventions reduce speech errors commonly observed in children with cleft (Sell et al., 2017). Innovations in telemedicine during COVID-19 have shown promising signs of the efficacy of delivering speech therapy remotely and this may be a great opportunity in LMICs going forward, especially for patients living in remote rural locations (Camden and Silva, 2021; Law et al., 2021; Pamplona and Ysunza, 2020).

Routine MDT assessments in dentistry, audiology, orthodontics, speech, psychology and surgery, as available within the local cleft team, were categorised as a medium priority because of the ability of these services to be delivered over a greater timescale without compromising outcomes. Pre-surgical orthopaedics was also categorised as a medium priority because despite its aim to improve tissue position and ultimately functional 
medRxiv preprint doi: https://doi.org/10.1101/2021.10.14.21265004; this version posted October 19, 2021. The copyright holder for this preprint (which was not certified by peer review) is the author/funder, who has granted medRxiv a license to display the preprint in

outcomes, it is not utilised universally, partly due to availability and partly due to the controversies surrounding efficacy (Hathaway and Long, 2014).

\section{DISCUSSION}

\section{Overview of process}

The structured process used in this study provided a positive collaborative experience, which should be encouraged in future global cleft endeavours. The condensed 6-week time period, with a pre-established 'finish-line', and a platform for the working group to present its recommendations, helped to increase intensity and provide urgency to the process. It became apparent that the variety of experience in the management of both $\mathrm{CL} / \mathrm{P}$ and COVID-19 provided a rich environment for discussion and mutual learning. Scheduling meetings on the videoconferencing platform at the same time and day of the week helped to provide consistency and improve attendance, given the working group members' multiple time zones and working commitments. It was helpful to specify focused aims from the outset of the process and to set tangible action points at the end of each group meeting. Encouraging continued discussion and the sharing of resources on virtual platforms between meetings helped to increase productivity. Consensus was achieved via identifying global areas of commonality and recognising areas of diversity and controversy.

\section{Summary of recommendations}

The working group was tasked to make recommendations regarding the adaptation of cleft care protocols during and after COVID-19 to help facilitate the provision of global comprehensive cleft care in LMICs. Foundational principles were set to respect the complex 
medRxiv preprint doi: https://doi.org/10.1101/2021.10.14.21265004; this version posted October 19, 2021. The copyright holder for this preprint (which was not certified by peer review) is the author/funder, who has granted medRxiv a license to display the preprint in

multidisciplinary nature of cleft care in resource-constrained settings and the specifics of local protocols, as it has been demonstrated that familiarity with a protocol is of primary importance for the achievement of good outcomes (Shaw and Semb, 2017). Within the broad topic of cleft protocols, the two areas that were focused upon were safety and prioritisation. First, recommendations about adaptations to surgical safety protocols were made that were categorised into pre, peri and post-operative phases. Adaptations are most likely to be required in the pre and peri-operative phases to identify and manage COVID-19 risk. Second, recommendations to prioritise surgical procedures and access to cleft services based on time-sensitivity and functional outcomes. Primary palatoplasty was prioritised due its intimate relationship with speech and maxillary growth outcome. Infant medical services, management of acute infections and speech pathology interventions were the most highly prioritised cleft services.

\section{Interpretation and implications:}

The WHO has documented the far-reaching impact of the COVID-19 pandemic in terms of the widespread disruption to essential health services, but elective services are being reestablished (World Health Organisation, 2021a). Global providers of cleft care will have to be prepared to adapt protocols to enable the comprehensive delivery of this essential health service. The literature and data on CL/P and COVID-19 is unsurprisingly sparse, given the relative infancy of the pandemic. (Salehi et al., 2021) have published recommendations for cleft and craniofacial outreach programs during the COVID-19 era with considerations for visiting teams before, during and after their visit away from their home country. The recommendations in current study focus instead on two important areas of the cleft 
medRxiv preprint doi: https://doi.org/10.1101/2021.10.14.21265004; this version posted October 19, 2021. The copyright holder for this preprint (which was not certified by peer review) is the author/funder, who has granted medRxiv a license to display the preprint in

protocol, and whilst applicable to visiting teams, are aimed at a wider audience of global cleft care providers in LMICs.

Safety is recognised to be of utmost importance when delivering cleft care (Kassam et al., 2020). The COVID-19 pandemic presents a safety dilemma because of the need to minimise the risk of the virus whilst balancing the risk of cleft treatment delays. The WHO has developed a useful facility assessment tool to enable rapid assessment of healthcare facilities to aid the provision of essential health services during the COVID pandemic (World Health Organisation, 2021b). More specifically for cleft, (Cai et al., 2021) reported management strategies to minimise the spread of the coronavirus during CLP treatment episodes in Shanghai. The collaborative group looked at safety protocols in common use before the pandemic and made recommendations on adaptations to consider specifically for COVID-19. Some of these adaptations, such as COVID-19 testing, will come at an increased monetary cost, and this is likely to be problematic in LMICs, where resources were already limited (Rossell-Perry and Gavino-Gutierrez, 2021). On the other hand, some COVID19 adaptations represent innovations and the advances in telemedicine in particular, which has proven to be successful for pre-operative COVID-19 screening and speech therapy delivery, may be well suited to LMICs (Ramanathan et al., 2021). Vaccinations provide a crucial part of the international COVID-19 response, and the current global vaccination inequity will stand to reduce access to comprehensive cleft care for children born in LMICs (Circle of Cleft Professionals, 2021c).

In a crowded healthcare system following delays to many areas of planned services, prioritisation of care will be vital. Breugem et al., (2020) conducted a survey of cleft 
medRxiv preprint doi: https://doi.org/10.1101/2021.10.14.21265004; this version posted October 19, 2021. The copyright holder for this preprint (which was not certified by peer review) is the author/funder, who has granted medRxiv a license to display the preprint in All rights reserved. No reuse allowed without permission.

priorities during COVID-19 with 218 cleft professionals in Europe, Asia and the USA. The respondents viewed airway intervention for Pierre Robin Sequence to be an emergency procedure. Primary palatoplasty was similarly thought to be a priority, but there was no consensus about timing, with $70 \%$ recommending before 15 months of age and $22 \%$ before 18 months of age. Speech surgery, alveolar bone grafting, placement of ear tubes and primary cleft lip repair were viewed to be time dependent and therefore warranted prioritisation. In the United Kingdom, all surgical procedures were prioritised into four categories of urgency by the Federation of Surgical Specialty Associations in July 2020 to expediate the recovery of surgical services during COVID (Federation of Surgical Specialty Associations, 2021). Primary palatoplasty and secondary speech surgery were initially categorised as priority 3 but were upgraded to priority 2 in February 2021 (see supplementary table 3) following advice from UK cleft professionals regarding the association with functional speech outcomes (Cleft Development Group, 2021). The recommendation in the UK was for primary palatoplasty, secondary speech surgery to be performed within 3 months of their target threshold ages specified in the national standards, with other cleft surgical procedures categorised as priority 4 to be performed in more than 3 months (NHS England, 2018). In the USA, cleft operations have also been categorised via a tiered system with reference to the ACPA operative target timing guidelines (Zimmerman et al., 2020).

The prioritisation of surgical procedures in this study purposefully did not incorporate specific threshold timings but instead categorised procedures into high, medium and lower priorities to reflect the degree of time-sensitivity with respect to functional outcomes. There was an emphasis to prioritise multidisciplinary cleft services equally alongside surgical 
medRxiv preprint doi: https://doi.org/10.1101/2021.10.14.21265004; this version posted October 19, 2021. The copyright holder for this preprint (which was not certified by peer review) is the author/funder, who has granted medRxiv a license to display the preprint in

procedures as these complete the comprehensive approach. A common theme with both strands was a prioritisation of speech outcomes, in recognition of the crucial role globally that speech plays in the life and social functioning of children born with $\mathrm{CL} / \mathrm{P}$.

\section{Strengths and limitations:}

The main strength of this piece of work was the collaborative nature of the international working group, which was inclusive of multiple disciplines and affiliation with multiple global cleft organisations. The working group was a good size in terms of productivity, but it was not inclusive of all specialties, organisations or regions and deliberations all took place in English.

The consensus recommendations were based on common principles, but this is not an exhaustive document and therefore not a comprehensive guide to delivering cleft care protocols in LMICs during and after COVID-19. It is hoped the efforts of cleft providers in resource-constrained settings will be supported by this work to present a united and coordinated case for the provision of comprehensive cleft care to policy makers and ultimately improve safety and outcomes for patients. Ideally, there should be a focus on local protocols and guidance, therefore the relevance of these recommendations in specific environments may be limited (Truche et al., 2020).

\section{Further work}

It is hoped that collaborative efforts such as this will galvanise the global cleft community to perform multi-centre international trials to reach a consensus on cleft care protocols and outcomes. Local outcome data collection must be encouraged to drive context-specific 
medRxiv preprint doi: https://doi.org/10.1101/2021.10.14.21265004; this version posted October 19, 2021. The copyright holder for this preprint (which was not certified by peer review) is the author/funder, who has granted medRxiv a license to display the preprint in

All rights reserved. No reuse allowed without permission.

guidance. Finally, the efficacy of innovations highlighted by this pandemic should be explored so that they can ultimately help with the provision of global cleft care.

\section{CONCLUSION}

The COVID-19 pandemic has had a detrimental impact on the delivery of comprehensive cleft care, which was already stretched in many areas of the world. As a global community, it is helpful for the providers of cleft care in LMICs to be able to recognise protocol adaptations that may be needed to deliver cleft care safely and elements that should be prioritised to maximise time-sensitive outcomes. A unified approach amongst global cleft care providers may help to lobby policy makers effectively at this crucial time of scarce resource allocation. 
medRxiv preprint doi: https://doi.org/10.1101/2021.10.14.21265004; this version posted October 19, 2021. The copyright holder for this preprint (which was not certified by peer review) is the author/funder, who has granted medRxiv a license to display the preprint in

\section{REFERENCES}

Allori AC, Kelley T, Meara JG, Albert A, Bonanthaya K, Chapman K, Cunningham M, DaskalogiannakisvJ, de Gier H, Heggie AA, Hernandez C, Jackson O, Jones Y, Kangesu L, Koudstaal MJ, Kuchhal R, Lohmander A, Long RE, Magee L, Monson L, Rose E, Sitzman TJ, Taylor JA, Thorburn G, van Eeden S, Williams C, Wirthlin JO, Wong KW. A Standard Set of Outcome Measures for the Comprehensive Appraisal of Cleft Care. Cleft Palate Craniofac J. 2017;54(5):540-554.

American Cleft Palate-Craniofacial Association 2020a. Statement on Cleft Lip/Palate related Surgeries and Team Care during the COVID-19 Pandemic. Available at: https://acpacpf.org/wp-content/uploads/2020/04/ACPA-Position-Statement-During-COVID19 4.1.2020.pdf. Accessed October 14, 2021.

American Cleft Palate-Craniofacial Association 2020b. Statement on Speech and Audiology

Services during the COVID-19 Pandemic. Available at: https://acpa-cpf.org/wpcontent/uploads/2020/04/ACPA-Position-Statement-During-COVID-19 Speech-andAudiology.pdf. Accessed October 14, 2021.

Breik O, Tivey D, Umapathysivam K, Anderson P. Mandibular distraction osteogenesis for the management of upper airway obstruction in children with micrognathia: a systematic review. Int J Oral Maxillofac Surg. 2016;45(6):769-782

Breugem CC, Evans KN, Poets CF, Suri S, Picard A, Filip C, Paes EC, Mehendale FV, Saal HM, Basart H, Murthy J, Joosten KFM, Speleman L, Collares MVM, van den Boogaard MJ, Muradin M, Andersson ME, Kogo M, Farlie PG, Don Griot P, Mossey PA, Slator R, Abadie V, Hong P. Best Practices for the Diagnosis and Evaluation of Infants With Robin Sequence. JAMA Pediatr. 2016;170(9).894-902.

Breugem C, Smit H, Mark H, Davies G, Schachner P, Collard M, Sell D, Autelitano L, Rezzonico A, Mazzoleni F, Novelli G, Mossey P, Persson M, Mehendale F, Gaggl A, van Gogh C, Zuurbier P, Reinart S, de Graaff F, Meazzini C. Prioritizing cleft/craniofacial surgical care after the COVID-19 pandemic. Plast Reconstr Surg Glob Open. 2020;8(9):e3080

Cai M, Zhao X, Chen L, Yuan W, Wang G, Wang X. The Preventive and Control Recommendations on Patient With Cleft Lip and Palate During COVID-19 Pandemic in Shanghai. J Craniofac Surg. 2021;32(2):e223-e226.

Camden C, Silva M. Pediatric Teleheath: Opportunities Created by the COVID-19 and Suggestions to Sustain Its Use to Support Families of Children with Disabilities. Phys Occup Ther Pediatr. 2021;41(1):1-17.

Carlson LC, Stewart BT, Hatcher KW, Kabetu C, VanderBurg R, Magee WP Jr. (2016). A Model of the Unmet Need for Cleft Lip and Palate Surgery in Low- and Middle-Income Countries. World J Surg. 2016;40(12):2857-2867.

Chapman KL, Hardin-Jones MA, Goldstein JA, Halter KA, Havlik RJ, Schulte J. Timing of palatal surgery and speech outcome. Cleft Palate Craniofac J. 2008;45(3):297-308.

Circle of Cleft Professionals 2021a. Available at: https://cleftcircle.org. Accessed October 14, 2021

Circle of Cleft Professionals 2021b. Solutions for Comprehensive Cleft Care. Available at:

https://solutions4ccc.com. Accessed October 14, 2021. 
medRxiv preprint doi: https://doi.org/10.1101/2021.10.14.21265004; this version posted October 19, 2021. The copyright holder for this preprint (which was not certified by peer review) is the author/funder, who has granted medRxiv a license to display the preprint in

All rights reserved. No reuse allowed without permission.

Circle of Cleft Professionals 2021c. Vaccine Equity Declaration. Available at:

https://transformingfaces.org/cocp/vaccine-health-worker-awareness-week/.

Accessed October 14, 2021

Cleft Development Group 2020. A message for cleft patients and their parents from the cleft teams in the UK and Ireland. Available at: https://www.clapa.com/news-item/amessage-from-uk-and-ireland-cleft-teams/. Accessed October 14, 2021

Cleft Development Group 2021. Minutes of a Meeting of the National UK NHS Cleft Development Group. Available at: https://www.cranedatabase.org.uk/content/uploads/2021/10/Confirmed_Minutes-of-a-Meeting-of-theNational-UK-NHS-Cleft-Development-Group 280521.pdf. Accessed October 14, 2021

Conroy, E. J., Cooper, R., Shaw, W., Persson, C., Willadsen, E., Munro, K. J., Williamson, P. R., Semb, G., Walsh, T., \& Gamble, C. (2021). A randomised controlled trial comparing palate surgery at 6 months versus 12 months of age (the TOPS trial): a statistical analysis plan. Trials, 22(1), 1-15. https://doi.org/10.1186/s13063-020-04886-y

de Ladeira, P. R. S., \& Alonso, N. (2012). Protocols in Cleft Lip and Palate Treatment: Systematic Review. Plastic Surgery International, 2012, 1-9.

https://doi.org/10.1155/2012/562892

Federation of Surgical Specialty Associations. Clinical Guide to Surgical Prioritisation During the Coronavirus Pandemic. Available at: https://fssa.org.uk/covid-19 documents.aspx. Accessed October 14, 2021.

Hardwicke J, Nassimizadeh M, Richard B. Reporting of randomized controlled trials in cleft lip and palate: A 10-year review. Cleft Palate Craniofac J. 2017;54(2):142-152.

Hathaway RR, Long RE Jr. Early cleft management: In search of evidence. Am J Orthod Dentofacial Orthop. 2014;145(2).135-141.

Kassam SN, Perry JL, Ayala R, Stieber E, Davies G, Hudson N, Hamdan US. World Cleft Coalition International Treatment Program Standards. Cleft Palate Craniofac J. 2020;57(10), 1171-1181.

Kuo CL, Lien CF, Chu CH, Shiao AS. Otitis media with effusion in children with cleft lip and palate: A narrative review. Int J Pediatr Otorhinolaryngol. 2013;77(9):1403-1409.

Law J, Dornstauder M, Charlton J, Gréaux M. Tele-practice for children and young people with communication disabilities: Employing the COM-B model to review the intervention literature and inform guidance for practitioners. Int J Lang Commun Disord. 2021;56(2).415-434

Lohmander A, Friede H, Lilja J. Long-term, longitudinal follow-up of individuals with unilateral cleft lip and palate after the Gothenburg primary early veloplasty and delayed hard palate closure protocol: Speech outcome. Cleft Palate Craniofac J. 2012 49(6), 657-671.

Ma X, Vervoort D, Reddy CL, Park KB, Makasa E. Emergency and essential surgical healthcare services during COVID-19 in low- and middle-income countries: A perspective. Int J Surg. 2020;79:43-46.

Mossey PA, Little J, Munger RG, Dixon MJ, Shaw WC. Cleft lip and palate. Lancet. 2009;374(9703):1773-1785.

Murray L, Hentges F, Hill J, Karpf J, Mistry B, Kreutz M, Woodall P, Moss T, Goodacre T. The effect of cleft lip and palate, and the timing of lip repair on mother-infant interactions and infant development. J Child Psychol Psychiatry. 2007;49(2):115-123 
medRxiv preprint doi: https://doi.org/10.1101/2021.10.14.21265004; this version posted October 19, 2021. The copyright holder for this preprint (which was not certified by peer review) is the author/funder, who has granted medRxiv a license to display the preprint in

All rights reserved. No reuse allowed without permission.

NHS England. Cleft Lip and/or Palate Quality Dashboard 2018/2019. Available at: https://www.england.nhs.uk/wp-content/uploads/2018/03/clp-metric-definitions2018-19.pdf. Accessed October 14, 2021.

Operation Smile. Medical Global Standards 2020. Available at: https://www.operationsmile.org/sites/default/files/2020\%20Medical\%20Global\%20Sta ndards\%20-English.pdf. Accessed October 14, 2021

Pamplona MDC, Ysunza PA. Speech pathology telepractice for children with cleft palate in the times of COVID-19 pandemic. Int J Pediatric Otorhinolaryngol. 2020;138:110318

Ramanathan M, Ravichandran SK, Parameswaran A. COVID-19 and Cleft and Craniofacial Surgery in Indian Scenario. J Maxillofac Oral Surg. 2021;19:1-6.

Rohrich RJ, Byrd HS. Optimal timing of cleft palate closure. Speech, facial growth, and hearing considerations. Clin Plast Surg. 1990;17(1):27-36.

Rossell-Perry P, Gavino-Gutierrez A. Cleft Lip and Palate Surgery during COVID-19 Pandemic. Plast Reconstr Surg Glob Open. 2021;9(6):e3692.

Rossell-Perry P, Luque-Tipula M. The Lima Surgical Protocol for Cleft Palate Repair. J Craniofac Surg. 2020;31(6):1533-1538.

Rotter, T., de Jong RB, Lacko SE, Ronellenfitsch, U., \& Kinsman, L. Clinical pathways as a quality strategy. In: Busse R, Klazinga N, Panteli D, Quentin W, editors. Improving healthcare quality in Europe: Characteristics, effectiveness and implementation of different strategies [Internet]. Copenhagen (Denmark): European Observatory on Health Systems and Policies; 2019:12.

Royal College of Paediatrics and Child Health 2020. National guidance for the recovery of elective surgery in children. Available at: https://www.rcpch.ac.uk/resources/nationalguidance-recovery-elective-surgery-children. Accessed October 14, 2021.

Salehi PP, Johnson AB, Rubinstein B, Pahlavan N, Azizzadeh B, Hamdan US. A Guide to Developing Safety Protocols for International Craniofacial Outreach Programs During the COVID-19 Era. J Craniofac Surg. 2021;32(1):e108-e110.

Schnitt DE, Agir H, David DJ. From Birth to Maturity: A Group of Patients Who Have Completed Their Protocol Management. Part I. Unilateral Cleft Lip and Palate. Plast Reconstr Surg. 2004;113(3):805-817.

Sell D, Mildinhall S, Albery L, Wills AK, Sandy JR, Ness AR. The Cleft Care UK study. Part 4: Perceptual speech outcomes. Orthod Craniofac Res. 2015;18(Suppl 2):36-46.

Sell D, Southby L, Wren Y, Wills AK, Hall A, Mahmoud O, Waylen A, Sandy JR, Ness AR. Centre-level variation in speech outcome and interventions, and factors associated with poor speech outcomes in 5-year-old children with non-syndromic unilateral cleft lip and palate: The Cleft Care UK study. Part 4. Orthod Craniofac Res. 2017;20(Suppl 2):27-39.

Semb G. Alveolar Bone Grafting. Front Oral Biol. 2012;16:124-136.

Sharratt ND, Agius JC, Davies G, Mehendale FV, Hagell P, Persson M. Equality in cleft and craniofacial care. Plast Aesthet Res. 2020;7:35

Shaw W, Semb G. The Scandcleft randomised trials of primary surgery for unilateral cleft lip and palate: 11. What next? J Plast Surg Hand Surg. 2017;51(1).88-93

Smile Train. Safety and Quality Protocol 2018. Available at: https://www.smiletrain.org/sites/default/files/2021-01/safety-quality-protocolenglish.pdf. Accessed October 14, 2021. 
medRxiv preprint doi: https://doi.org/10.1101/2021.10.14.21265004; this version posted October 19, 2021. The copyright holder for this preprint (which was not certified by peer review) is the author/funder, who has granted medRxiv a license to display the preprint in All rights reserved. No reuse allowed without permission.

Stoehr JR, Hamidian Jahromi A, Chu QD, Zibari GB, Gosain AK. Considerations for resuming global surgery outreach programs during and after the coronavirus disease 2019 (COVID-19) pandemic. Surgery. 2021;25:S0039-6060(21)00448-7

Truche P, Bowder A, Lalla AT, Crum R, Botelho F, Rice HE, Lopes BC, Greenberg S, Evans F, Meara JG, Ameh EA, Mooney DP. Perspectives on perioperative management of children's surgical conditions during the COVID-19 pandemic in low-income and middle-income countries: a global survey. World J Pediatr Surg. 2020;3(3):e000187.

Vander Burg R, Agrawal K, Desai P, Desalu I, Donkor P. Impact of COVID-19 on Elective Cleft Surgery in Low- and Middle-income Countries. Plast Reconstr Surg Glob Open. 2021;9(6):e3656.

Weidler EM, Britto MT, Sitzman TJ. Facilitators and Barriers to Implementing Standardized Outcome Measurement for Children With Cleft Lip and Palate. Cleft Palate Craniofac J. 2021;58(1):7-18.

World Health Organisation 2021a. Second round of the national pulse survey on continuity of essential health services during the COVID-19 pandemic. Available at: https://www.who.int/publications/i/item/WHO-2019-nCoV-EHS-continuity-survey2021.1. Accessed October 14, 2021

World Health Organisation 2021b. Continuity of essential health services: Facility assessment tool: a module from the suite of health service capacity assessments in the context of COVID-19 pandemic: interim guidance, 12 May 2021. Available at: https://apps.who.int/iris/handle/10665/341306?show=full. Accessed October 14, 2021

World Health Organisation 2003. WHO Generic Essential Emergency Equipment List. Available at: https://www.who.int/surgery/publications/EEEGenericlist revAug2012.pdf?ua=1. Accessed October 14, 2021.

Zimmerman CE, Humphries LS, Taylor JA. A Tiered System to Guide Prioritization of Pediatric Cleft and Craniofacial Cases in COVID-19. Plast Reconstr Surg. 2020;146(3):392e-394e.

\section{FIGURES LEGENDS}

1. A flow diagram to describe an overview of the process used

\section{TABLES LEGENDS}

1. The composition of the working group

2. Cleft surgery safety measures that were routine before COVID and specific adaptations for consideration during and after COVID 
medRxiv preprint doi: https://doi.org/10.1101/2021.10.14.21265004; this version posted October 19, 2021. The copyright holder for this preprint (which was not certified by peer review) is the author/funder, who has granted medRxiv a license to display the preprint in All rights reserved. No reuse allowed without permission.

3. Recommended time-sensitive prioritisation of surgical procedures and access to comprehensive cleft care

\section{SUPPLEMENTARY MATERIAL}

Supplementary Figure 1: Results of Circle of Cleft Professionals COVID Survey: Question 10.

What are the topics you (or members of your team) would be most interested in learning more about?

Supplementary Figure 2: Levels of evidence used by the working group to consider literature

Supplementary Table 1: Evidence that timing of palatoplasty is associated with speech outcome

Supplementary Table 2: Evidence that the timing of primary palatoplasty is associated with maxillary growth outcome

Supplementary Table 3: The Federation of Surgical Specialty Associations Surgical Prioritisation System - first published June 2020. Updated in February 2021. The priority levels assigned to cleft operations are indicated both initially in July 2020 and later in February 2021. 


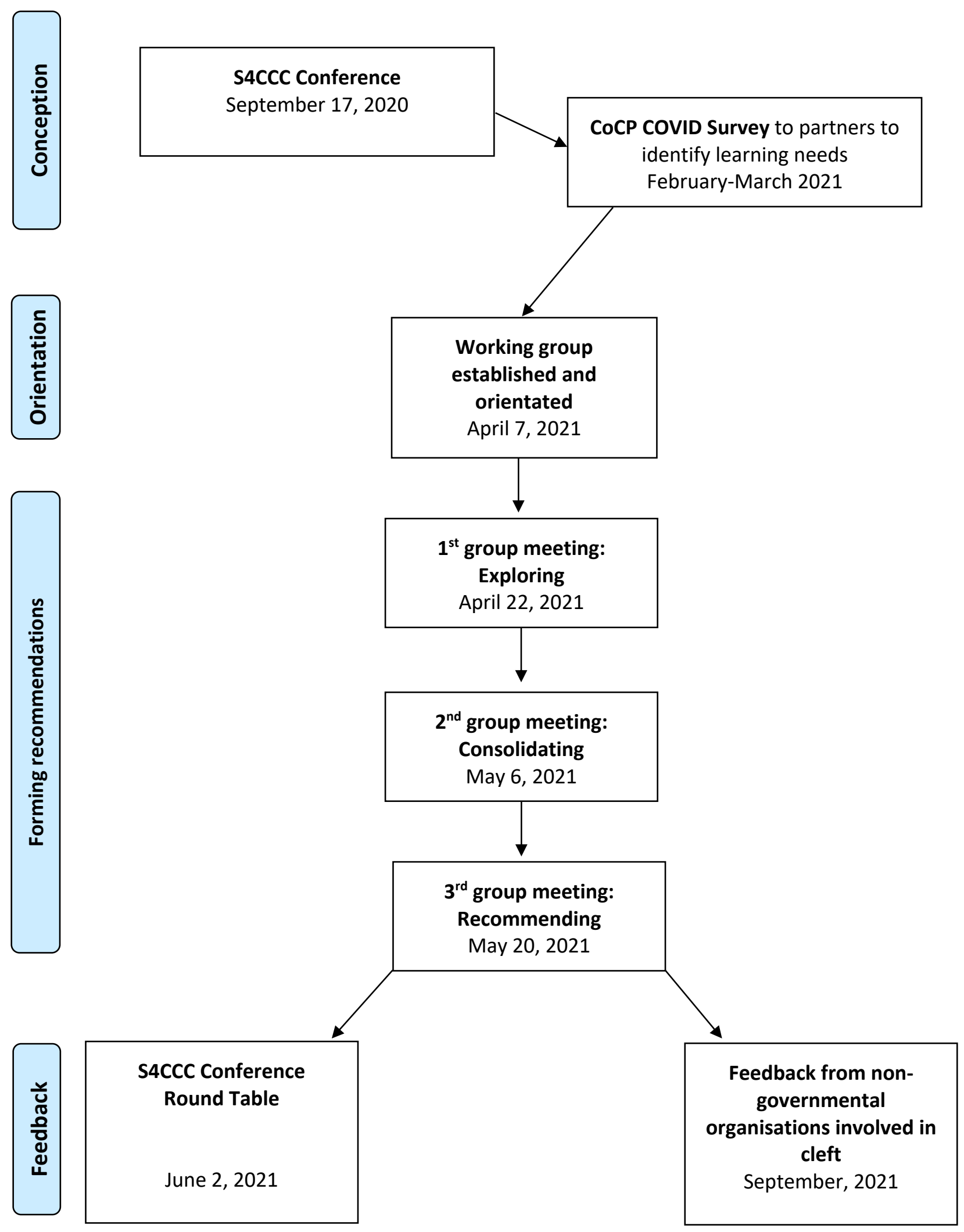


medRxiv preprint doi: https://doi.org/10.1101/2021.10.14.21265004; this version posted October 19, 2021. The copyright holder for this preprint (which was not certified by peer review) is the author/funder, who has granted medRxiv a license to display the preprint in All rights reserved. No reuse allowed without permission.

Table 1: The composition of the working group

\begin{tabular}{|c|c|c|c|c|}
\hline Name & Group Role & Location & $\begin{array}{l}\text { Clinical } \\
\text { Discipline }\end{array}$ & $\begin{array}{l}\text { Organisation } \\
\text { Affiliations }\end{array}$ \\
\hline Fell, M & Co-Chair & $\begin{array}{l}\text { United } \\
\text { Kingdom }\end{array}$ & $\begin{array}{l}\text { Plastic Surgery } \\
\text { Trainee }\end{array}$ & $\begin{array}{l}\text { The Cleft Collective + } \\
\text { CLEFT Charity }\end{array}$ \\
\hline Goldschmied, K & Co-Chair & Chile & $\begin{array}{l}\text { Speech and } \\
\text { Language } \\
\text { Therapist }\end{array}$ & $\begin{array}{l}\text { Hospital Dr Luis Calvo } \\
\text { Mackenna }\end{array}$ \\
\hline Goldwasser, M & Member & USA & $\begin{array}{l}\text { Professor of } \\
\text { Surgery }\end{array}$ & $\begin{array}{l}\text { Operation Smile + } \\
\text { University of North } \\
\text { Carolina }\end{array}$ \\
\hline Jayanth, BS & Member & India & Cleft Surgeon & $\begin{array}{l}\text { ABMSS Comprehensive } \\
\text { Cleft Care }\end{array}$ \\
\hline Pereira, RMR & Member & Brazil & Cleft Surgeon & University of Sau Paulo \\
\hline Nawej, CT & Member & $\begin{array}{l}\text { Democratic } \\
\text { Republic of } \\
\text { the Congo }\end{array}$ & Anaesthetist & $\begin{array}{l}\text { University of } \\
\text { Lubumbashi }\end{array}$ \\
\hline Winner, $\mathrm{R}$ & Co-ordinator & Canada & Non-clinical & Transforming Faces \\
\hline
\end{tabular}


medRxiv preprint doi: https://doi.org/10.1101/2021.10.14.21265004; this version posted October 19, 2021. The copyright holder for this preprint (which was not certified by peer review) is the author/funder, who has granted medRxiv a license to display the preprint in All rights reserved. No reuse allowed without permission.

Table 2: Cleft surgery safety measures that were routine before COVID-19 and specific adaptations for consideration during and after COVID-19

\begin{tabular}{|c|c|c|}
\hline Period & $\begin{array}{l}\text { Routine pre-COVID-19 safety } \\
\text { measures }\end{array}$ & $\begin{array}{l}\text { Suggested adaptations during and } \\
\text { after COVID-19 }\end{array}$ \\
\hline \multirow[t]{7}{*}{$\begin{array}{l}\text { Pre- } \\
\text { surgical }\end{array}$} & $\begin{array}{l}\text { Pre-op review by surgeon and } \\
\text { anaesthetist }\end{array}$ & Monitoring regional COVID prevalence \\
\hline & Vital signs and weight & Virtual screening pre-op \\
\hline & Blood tests & Consider the need for pre-op isolation \\
\hline & & $\begin{array}{l}\text { COVID-19 vaccination status for } \\
\text { patients and staff }\end{array}$ \\
\hline & & Patient testing with RT-PCR \\
\hline & & Staff testing with RT-PCR \\
\hline & & Protocol if COVID-19 positive \\
\hline \multirow[t]{10}{*}{$\begin{array}{l}\text { Peri- } \\
\text { surgical }\end{array}$} & $\begin{array}{l}\text { Multidisciplinary care by trained } \\
\text { professionals }\end{array}$ & $\begin{array}{l}\text { Allow for time delays due to COVID-19 } \\
\text { precautions }\end{array}$ \\
\hline & $\begin{array}{l}\text { Appropriate paediatric medical and } \\
\text { surgical facilities with adequate } \\
\text { equipment and access to high } \\
\text { dependency care }\end{array}$ & $\begin{array}{l}\text { Skills and equipment to care for } \\
\text { COVID-19 positive patients and staff }\end{array}$ \\
\hline & Hygiene and running water & Isolation and quarantine facilities \\
\hline & PPE for operating theatre staff & PPE for all staff, patients and families \\
\hline & Crisis notification plan & Distancing measures within facility \\
\hline & Emergency arrest protocol & Consent to include COVID risk \\
\hline & Paediatric Anaesthetic services & $\begin{array}{l}\text { Minimise family members to reduce } \\
\text { people at risk }\end{array}$ \\
\hline & Informed consent process & \\
\hline & $\begin{array}{l}\text { Safeguarding procedures for } \\
\text { vulnerable people }\end{array}$ & \\
\hline & WHO surgical checklist & \\
\hline \multirow[t]{4}{*}{$\begin{array}{l}\text { Post- } \\
\text { surgical }\end{array}$} & $\begin{array}{l}\text { Immediate post-operative pathways } \\
\text { and observation }\end{array}$ & \\
\hline & $\begin{array}{l}\text { Weigh risk/benefit for inpatient } \\
\text { versus outpatient care }\end{array}$ & \\
\hline & $\begin{array}{l}\text { Weigh risk/benefit for physical } \\
\text { versus virtual follow-up }\end{array}$ & \\
\hline & $\begin{array}{l}\text { Recording of outcomes and on-going } \\
\text { monitoring }\end{array}$ & \\
\hline
\end{tabular}


medRxiv preprint doi: https://doi.org/10.1101/2021.10.14.21265004; this version posted October 19, 2021. The copyright holder for this preprint (which was not certified by peer review) is the author/funder, who has granted medRxiv a license to display the preprint in

All rights reserved. No reuse allowed without permission.

Table 3: Recommended time-sensitive prioritisation of surgical procedures and access to comprehensive cleft care

\begin{tabular}{|c|c|c|}
\hline Priority & Surgical Procedures & Access to cleft care \\
\hline \multirow[t]{4}{*}{ High } & Respiratory access if required in PRS & $\begin{array}{l}\text { New-born cleft babies need to be } \\
\text { assessed regarding breathing, feeding } \\
\text { and hearing, and families need to be } \\
\text { counselled appropriately }\end{array}$ \\
\hline & $\begin{array}{l}\text { Primary cleft palate repair (+- middle } \\
\text { ear tubes) }\end{array}$ & $\begin{array}{l}\text { Ongoing paediatric and nutritional } \\
\text { support care (especially for syndromes) }\end{array}$ \\
\hline & & Dental or ENT Infections (otitis media) \\
\hline & $\begin{array}{l}\text { Mandible distraction if required for } \\
\text { nutrition (if integrated in local } \\
\text { protocol) }\end{array}$ & Speech Pathology intervention \\
\hline \multirow[t]{4}{*}{ Medium } & Primary cleft lip reconstruction & $\begin{array}{l}\text { Routine Speech, Audiology, Dental, } \\
\text { Orthodontic and Psychosocial } \\
\text { assessment and advice }\end{array}$ \\
\hline & Secondary Speech Surgery & $\begin{array}{l}\text { Pre-surgical orthopaedics (if used } \\
\text { within local protocol) }\end{array}$ \\
\hline & Symptomatic Fistula Repair & \\
\hline & Secondary Alveolar Bone Grafting & \\
\hline \multirow[t]{3}{*}{ Lower } & Orthognathic surgery & \\
\hline & $\begin{array}{l}\text { Secondary Rhinoplasty and } \\
\text { Revisional cleft lip Surgery }\end{array}$ & \\
\hline & Routine dental procedures & \\
\hline
\end{tabular}


medRxiv preprint doi: https://doi.org/10.1101/2021.10.14.21265004; this version posted October 19, 2021. The copyright holder for this preprint (which was not certified by peer review) is the author/funder, who has granted medRxiv a license to display the preprint in perpetuity.

All rights reserved. No reuse allowed without permission.

\section{Supplementary data}

Supplementary Figure 1: Circle of Cleft Professionals Questionnaire and results

10. What are the topics you (or members of your team) would be most interested in learning more about? (Select as many as apply)

Answered: 175 skipped:0

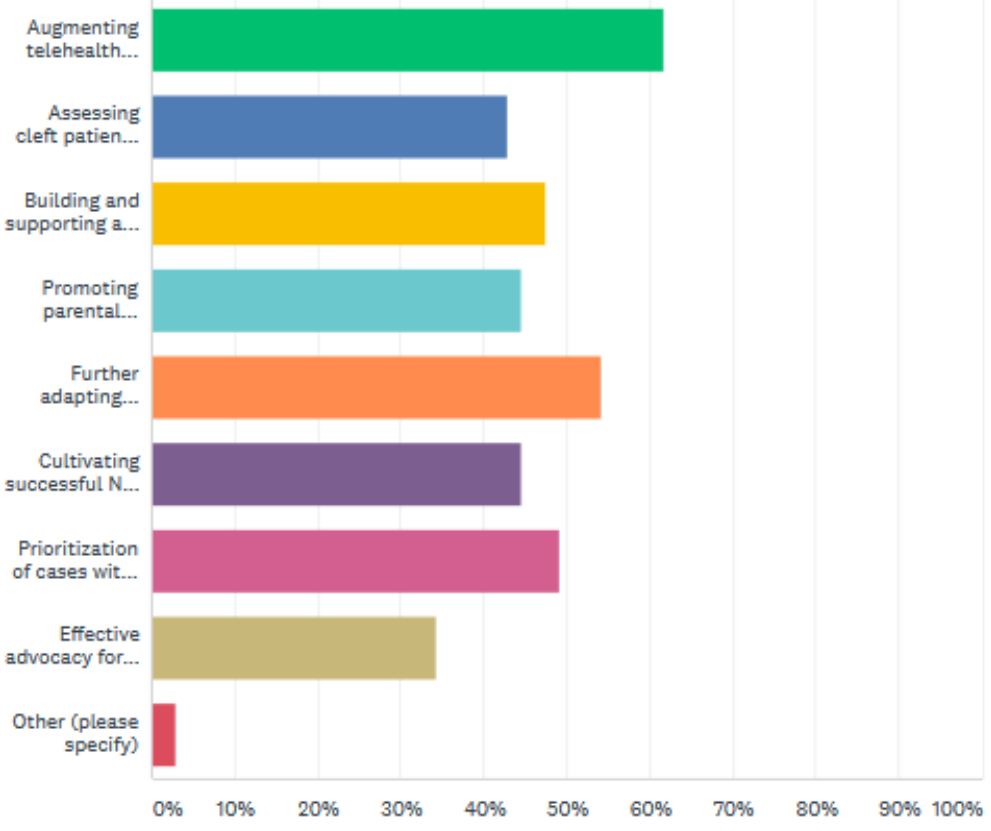

\begin{tabular}{|c|c|c|c|}
\hline ANSWER CHOICES & - & RESPONSES & 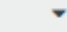 \\
\hline Augmenting telehealth strategies for cleft patients & & $61.71 \%$ & 108 \\
\hline - Assessing cleft patient outcomes during the pandemic & & $42.86 \%$ & 76 \\
\hline Building and supporting a resilient $\mathrm{CCC}$ team & & $47.43 \%$ & 83 \\
\hline Promoting parental engagement during the pandemic & & $44.57 \%$ & 78 \\
\hline Further adapting COVID-19 cleft care protocols in light of evidence-based research & & $54.29 \%$ & 96 \\
\hline Cultivating successful NGO / local CCC team collaboration during the pandemic & & $44.57 \%$ & 78 \\
\hline - Prioritization of cases within a cleft patient backlog & & $49.14 \%$ & 86 \\
\hline Effective advocacy for increased access to COVID-19 vaccination & & $34.29 \%$ & 60 \\
\hline Other (please specify) & Responses & $2.86 \%$ & 5 \\
\hline
\end{tabular}

Supplementary Figure 2: Levels of evidence used by the working group to consider literature 
medRxiv preprint doi: https://doi.org/10.1101/2021.10.14.21265004; this version posted October 19, 2021. The copyright holder for this preprint (which was not certified by peer review) is the author/funder, who has granted medRxiv a license to display the preprint in

All rights reserved. No reuse allowed without permission.

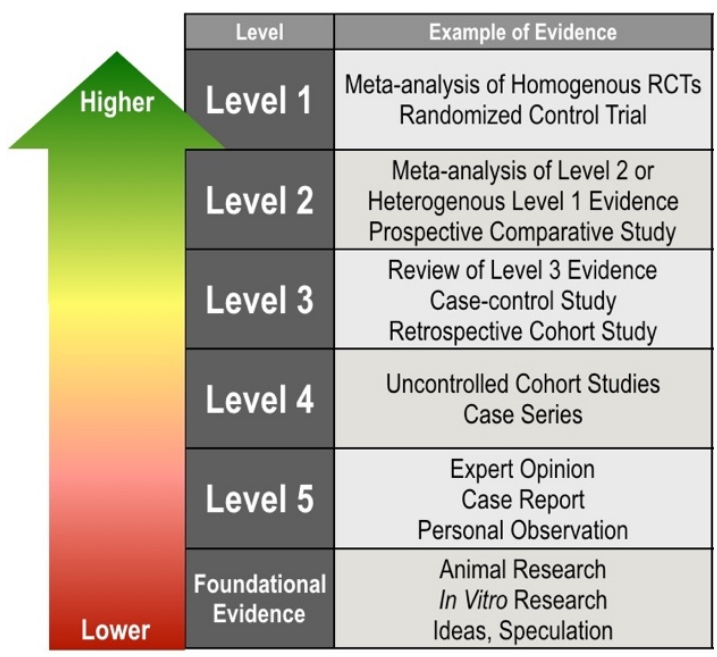

Supplementary Table 1: Evidence that timing of palatoplasty is associated with speech outcome

\begin{tabular}{|c|c|c|c|}
\hline Resource title & $\begin{array}{l}\text { Level of } \\
\text { Evidence }\end{array}$ & Overview of resource & Conclusion \\
\hline $\begin{array}{l}\text { SCANDCLEFT } \\
\text { Trials } \\
\text { (Lohmander et } \\
\text { al., 2017) } \\
\text { (Willadsen et al., } \\
\text { 2017) }\end{array}$ & 1 & $\begin{array}{l}\text { RCT comparing } 4 \text { 2-stage } \\
\text { surgical protocols for complete } \\
\text { UCLP ( } n= \\
\text { Hard palate closure at } 12 \\
\text { versus } 36 \text { months was } \\
\text { compared }\end{array}$ & $\begin{array}{l}\text { No difference in } \\
\text { resonance (nasality) } \\
\text { Later palate closure } \\
\text { associated with poorer } \\
\text { consonant proficiency }\end{array}$ \\
\hline $\begin{array}{l}\text { (Willadsen et al., } \\
\text { 2018) } \\
\text { Denmark }\end{array}$ & 1 & $\begin{array}{l}\text { RCT } 126 \text { children with UCLP to } \\
\text { compare hard palate closure at } \\
12 \text { months versus } 36 \text { months }\end{array}$ & $\begin{array}{l}\text { Early hard palate closure } \\
\text { associated with better } \\
\text { consonant production } \\
\text { and fewer active cleft } \\
\text { speech characteristic } \\
\text { errors }\end{array}$ \\
\hline $\begin{array}{l}\text { (Willadsen, 2012) } \\
\text { Denmark }\end{array}$ & 1 & $\begin{array}{l}\text { RCT } 34 \text { children with UCLP } \\
\text { SP closure at } 4 \text { months, HP } \\
\text { closure at } 12 \text { months or } 36 \\
\text { months }\end{array}$ & $\begin{array}{l}\text { Speech outcomes better } \\
\text { in early repair group - } \\
12 \text { months. }\end{array}$ \\
\hline $\begin{array}{l}\text { (Williams et al., } \\
\text { 2011) } \\
\text { Brazil }\end{array}$ & 1 & $\begin{array}{l}\text { RCT comparing primary palate } \\
\text { closure at } 9-12 \text { months versus } \\
15-18 \text { months }\end{array}$ & $\begin{array}{l}\text { No statistical difference } \\
\text { in resonance }\end{array}$ \\
\hline $\begin{array}{l}\text { (Shaffer et al., } \\
\text { 2020) }\end{array}$ & 4 & $\begin{array}{l}\text { Retrospective review } 733 \\
\text { children born } 2005-15\end{array}$ & $\begin{array}{l}\text { Late palatoplasty } \\
\text { associated with }\end{array}$ \\
\hline
\end{tabular}


medRxiv preprint doi: https://doi.org/10.1101/2021.10.14.21265004; this version posted October 19, 2021. The copyright holder for this preprint (which was not certified by peer review) is the author/funder, who has granted medRxiv a license to display the preprint in perpetuity.

All rights reserved. No reuse allowed without permission.

\begin{tabular}{|c|c|c|c|}
\hline & & $\begin{array}{l}\text { Age at palatoplasty: Early: } \\
<11 \text { mnths, } n=28 ; \\
\text { Standard: } 11-13 \text { mnths, } n=158 \text {; } \\
\text { Late: }>13 \text { mnths, } n=46\end{array}$ & $\begin{array}{l}\text { increased speech and } \\
\text { language delay. } \\
\text { Speech sound } \\
\text { production disorders, } \\
\text { VPI and hearing loss } \\
\text { were not significantly } \\
\text { associated with age at } \\
\text { palatoplasty }\end{array}$ \\
\hline $\begin{array}{l}\text { (Kara et al., 2020) } \\
\text { Turkey }\end{array}$ & 4 & $\begin{array}{l}\text { Retrospective review of } 416 \\
\text { cleft palate patients who had } \\
\text { palate repair before } 12 \\
\text { months, } 12-18 \text { months and }>18 \\
\text { months }\end{array}$ & $\begin{array}{l}\text { Palate repairs after } 18 \\
\text { months had worse } \\
\text { speech }\end{array}$ \\
\hline $\begin{array}{l}\text { (Swanson et al., } \\
\text { 2017) }\end{array}$ & 4 & $\begin{array}{l}\text { Retrospective review of } 40 \\
\text { patients with submucous } \\
\text { palate }\end{array}$ & $\begin{array}{l}\text { Better speech outcomes } \\
\text { in patients repaired } \\
\text { before } 4 \text { years of age }\end{array}$ \\
\hline $\begin{array}{l}\text { (Follmar et al., } \\
\text { 2015) }\end{array}$ & 4 & $\begin{array}{l}\text { 13yr retrospective review of } \\
201 \text { internationally adopted } \\
\text { patients } 1993-2006.183 \\
\text { surgery before } 18 \text { months, } 18 \\
\text { performed after } 18 \text { months. } \\
33 \% \text { of delayed group } \\
\text { developed VPI compared } 13 \% \\
\text { of those repaired at }<18 \\
\text { months ( } p=0.03 \text { ) }\end{array}$ & $\begin{array}{l}\text { Internationally adopted } \\
\text { children whose palate } \\
\text { was repaired after } 18 \\
\text { months were more likely } \\
\text { to develop speech } \\
\text { symptoms of VPI. }\end{array}$ \\
\hline $\begin{array}{l}\text { (Pasick et al., } \\
\text { 2014) }\end{array}$ & 4 & $\begin{array}{l}\text { Retrospective review of } 24 \\
\text { patients : palatoplasty at }>18 \\
\text { months }\end{array}$ & $\begin{array}{l}\text { Palate repair after } 18 / 12 \\
\text { associated with } \\
\text { significantly increased } \\
\text { incidence of articulation } \\
\text { errors associated with } \\
\text { VPI }\end{array}$ \\
\hline $\begin{array}{l}\text { (Yang et al., } \\
\text { 2013) }\end{array}$ & 4 & $\begin{array}{l}\text { Retrospective review of } 503 \\
\text { patients with non-syndromic } \\
\text { cleft palate }\end{array}$ & $\begin{array}{l}\text { Repair before } 2 \text { years of } \\
\text { age had better } \\
\text { velopharyngeal } \\
\text { competence }\end{array}$ \\
\hline $\begin{array}{l}\text { (Chapman et al., } \\
\text { 2008) }\end{array}$ & 4 & $\begin{array}{l}40 \text { children with non- } \\
\text { syndromic cleft palate repaired } \\
\text { primarily in younger age (mean } \\
11 \text { months) and older age } \\
\text { (mean } 15 \text { months) assessed at } \\
\text { age } 3 \text { years. }\end{array}$ & $\begin{array}{l}\text { At age } 3 \text { years children } \\
\text { who had palate surgery } \\
\text { prior to the onset of } \\
\text { words had better } \\
\text { articulation and } \\
\text { resonance outcomes } \\
\text { than those who had } \\
\text { surgery after the onset } \\
\text { of words. }\end{array}$ \\
\hline $\begin{array}{l}\text { (Hardin-Jones \& } \\
\text { Jones, 2005) }\end{array}$ & 4 & 212 preschoolers with clefts & $\begin{array}{l}\text { Significant relationship } \\
\text { between age at palatal }\end{array}$ \\
\hline
\end{tabular}


medRxiv preprint doi: https://doi.org/10.1101/2021.10.14.21265004; this version posted October 19, 2021. The copyright holder for this preprint (which was not certified by peer review) is the author/funder, who has granted medRxiv a license to display the preprint in perpetuity.

All rights reserved. No reuse allowed without permission.

\begin{tabular}{|c|c|c|c|}
\hline & & & $\begin{array}{l}\text { surgery and prevalence } \\
\text { of hypernasality } \\
\text { advocated primary } \\
\text { repair before } 13 \text { months }\end{array}$ \\
\hline $\begin{array}{l}\text { (Rezaei et al., } \\
\text { 2020) } \\
\text { Iran }\end{array}$ & 4 & $\begin{array}{l}\text { Retrospective review of } 180 \\
\text { patients - comparison made } \\
\text { between primary palate repair } \\
\text { before and after } 13 \text { months }\end{array}$ & $\begin{array}{l}\text { Late surgery group had } \\
\text { significantly worse } \\
\text { articulation errors and } \\
\text { more likely to have } \\
\text { moderate/severe } \\
\text { hypernasality }\end{array}$ \\
\hline $\begin{array}{l}\text { CRANE Database } \\
\text { UK } \\
\text { (CRANE, 2020) }\end{array}$ & 4 & $\begin{array}{l}\text { Comparing speech outcomes } \\
\text { with timing of surgery for } 789 \\
\text { non-syndromic children born } \\
2007-2013 \text {. Significant } \\
\text { difference in speech outcome } \\
\text { with those having surgery at } \\
\text { 14+ months doing significantly } \\
\text { worse on all } 3 \text { UK speech } \\
\text { standard outcomes. }\end{array}$ & $\begin{array}{l}\text { Speech outcomes better } \\
\text { in children who have } \\
\text { speech surgery before } \\
14 \text { months of age. }\end{array}$ \\
\hline $\begin{array}{l}\text { (Marrinan et al., } \\
\text { 1998) }\end{array}$ & 4 & $\begin{array}{l}\text { Retrospective study of } 228 \\
\text { non-syndromic patients with } 2 \\
\text { surgeons. Significant linear } \\
\text { association ( } p=.025 \text { ) between } \\
\text { age at repair and VPI. }\end{array}$ & $\begin{array}{l}\text { Patients in the early } \\
\text { repair group (8-10 } \\
\text { months) were least } \\
\text { likely to need secondary } \\
\text { treatment for VPI. }\end{array}$ \\
\hline $\begin{array}{l}\text { (Dorf \& Curtin, } \\
\text { 1982) }\end{array}$ & 4 & $\begin{array}{l}21 \text { children surgery before } 12 \\
\text { months, } \\
59 \text { surgery after } 12.5 \text { months } \\
10 \% \text { in early group had } \\
\text { compensatory articulations } \\
\text { compared to } 86 \% \text { in late group }\end{array}$ & $\begin{array}{l}\text { Worse articulation } \\
\text { outcomes for children } \\
\text { whose palate surgery } \\
\text { was completed before } \\
12 \text { months compared to } \\
\text { those completed after } \\
12 \text { months. }\end{array}$ \\
\hline $\begin{array}{l}\text { (Peterson- } \\
\text { Falzone, 1996) }\end{array}$ & 5 & $\begin{array}{l}\text { A non-systematic review of the } \\
\text { evidence on timing of palate } \\
\text { surgery and speech outcome }\end{array}$ & $\begin{array}{l}\text { The effects of structural } \\
\text { constraints on phonetic } \\
\text { and phonological } \\
\text { development in children } \\
\text { supports efforts towards } \\
\text { earlier surgery ( }<12 \\
\text { months).General trend } \\
\text { in the literature of } \\
\text { better speech results in } \\
\text { earlier surgery }\end{array}$ \\
\hline
\end{tabular}


medRxiv preprint doi: https://doi.org/10.1101/2021.10.14.21265004; this version posted October 19, 2021. The copyright holder for this preprint (which was not certified by peer review) is the author/funder, who has granted medRxiv a license to display the preprint in All rights reserved. No reuse allowed without permission.

Supplementary Table 2: Evidence that the timing of primary palatoplasty is associated with maxillary growth outcome

\begin{tabular}{|c|c|c|c|}
\hline $\begin{array}{l}\text { Study /Personal } \\
\text { Experience }\end{array}$ & $\begin{array}{l}\text { Level of } \\
\text { Evidence }\end{array}$ & Overview & Conclusion \\
\hline $\begin{array}{l}\text { (Pereira et al., } \\
\text { 2018) } \\
\text { Brazil }\end{array}$ & 1 & $\begin{array}{l}\text { Single centre RCT of } 64 \text { patients to } \\
\text { evaluate early complete palate repair } \\
\text { (9-15 months) vs late hard palate repair } \\
\text { ( } 3-4 \text { years) }\end{array}$ & $\begin{array}{l}\text { Delayed hard } \\
\text { palate repair } \\
\text { had better } \\
\text { dentofacial } \\
\text { growth }\end{array}$ \\
\hline $\begin{array}{l}\text { Scandcleft Trials } \\
\text { (Küseler et al., } \\
\text { 2019) } \\
\text { (Heliövaara et al., } \\
2017 \text { ) } \\
\text { (Karsten et al., } \\
\text { 2017) }\end{array}$ & 1 & $\begin{array}{l}\text { Part of a multi-centre RCT of } 429 \\
\text { patients compared early ( } 12 \text { months) } \\
\text { versus late ( } 36 \text { months) hard palate } \\
\text { repair. Maxillary growth measured using } \\
\text { models at } 5 \text { years and cephalometry at } \\
8 \text { years }\end{array}$ & $\begin{array}{l}\text { No difference } \\
\text { in maxillary } \\
\text { growth by } 8 \\
\text { years of age }\end{array}$ \\
\hline $\begin{array}{l}\text { (Botticelli et al., } \\
\text { 2019) } \\
\text { Denmark but } \\
\text { included in } \\
\text { Scandcleft }\end{array}$ & 1 & $\begin{array}{l}\text { Single centre RCT of } 122 \text { UCLP to } \\
\text { compare hard palate closure at } 12 \text { or } 36 \\
\text { months - assessment on models at } 8 \\
\text { years of age }\end{array}$ & $\begin{array}{l}\text { No conclusion } \\
\text { about which } \\
\text { was favourable } \\
\text { - delayed } \\
\text { repair had } \\
\text { better } \\
\text { transverse } \\
\text { dimension but } \\
\text { had a shallower } \\
\text { morphology }\end{array}$ \\
\hline $\begin{array}{l}\text { (Salgado et al., } \\
\text { 2019) }\end{array}$ & 4 & $\begin{array}{l}\text { A systematic review or early vs delayed } \\
\text { palatoplasty and effect on growth - } 5 \\
\text { included observational studies } \\
\text { - Daskalogiannakis et al., } 2006 \\
\text { - Holland et al., } 2007 \\
\text { - Yaminishi et al., } 2011 \\
\text { - Zemann et al., } 2011 \\
\text { - Bakri et al., } 2014 \\
\end{array}$ & $\begin{array}{l}\text { Conflicting } \\
\text { results } \\
\text { between the } \\
\text { five studies - } \\
\text { no conclusion } \\
\text { made }\end{array}$ \\
\hline (Xu et al., 2012) & 4 & $\begin{array}{l}\text { Retrospective series of } 46 \text { UCLP to } \\
\text { compare palatoplasty before and after } 4 \\
\text { years of age }\end{array}$ & $\begin{array}{l}\text { Better maxillary } \\
\text { growth } \\
\text { associated with } \\
\text { later repairs }\end{array}$ \\
\hline $\begin{array}{l}\text { (Y.-F. Liao et al., } \\
\text { 2010) }\end{array}$ & 4 & $\begin{array}{l}\text { Retrospective series of } 72 \text { cUCLP to } \\
\text { compare one stage versus two-stage }\end{array}$ & $\begin{array}{l}\text { Delayed hard } \\
\text { palate } \\
\text { associated with }\end{array}$ \\
\hline
\end{tabular}


medRxiv preprint doi: https://doi.org/10.1101/2021.10.14.21265004; this version posted October 19, 2021. The copyright holder for this preprint (which was not certified by peer review) is the author/funder, who has granted medRxiv a license to display the preprint in

All rights reserved. No reuse allowed without permission.

\begin{tabular}{|l|l|l|l|}
\hline & & $\begin{array}{l}\text { with delayed hard palate repair. } \\
\text { Cephalometry at 20 years. }\end{array}$ & $\begin{array}{l}\text { better maxillary } \\
\text { growth }\end{array}$ \\
\hline $\begin{array}{l}\text { (Y.-F. Liao \& } \\
\text { Mars, 2006) }\end{array}$ & 3 & $\begin{array}{l}\text { A systematic review of timing of palate } \\
\text { repair on facial growth - 15 } \\
\text { observational studies included }\end{array}$ & $\begin{array}{l}\text { No conclusive } \\
\text { evidence that } \\
\text { timing affects } \\
\text { growth }\end{array}$ \\
\hline $\begin{array}{l}\text { (Y. F. Liao et al., } \\
\text { 2006) }\end{array}$ & 4 & $\begin{array}{l}\text { Retrospective series of 104 patients in } \\
\text { Sri Lanka who had their palate repaired } \\
\text { by 13 years of age }\end{array}$ & $\begin{array}{l}\text { Later age of } \\
\text { repair was } \\
\text { associated with } \\
\text { better AP } \\
\text { growth of the } \\
\text { maxilla }\end{array}$ \\
\hline (Friede, 2007) & 5 & $\begin{array}{l}\text { Personal perspectives of delayed hard } \\
\text { palate closure }\end{array}$ & $\begin{array}{l}\text { Advocates } \\
\text { delayed hard } \\
\text { palate closure } \\
\text { at 1-1.5 years } \\
\text { to achieve } \\
\text { better growth }\end{array}$ \\
\hline
\end{tabular}

Supplementary Table 3: The Federation of Surgical Specialty Associations Surgical Prioritisation System - first published June 2020. Updated in February 2021. The priority levels assigned to cleft operations are indicated both initially in July 2020 and later in February 2021.

\begin{tabular}{|c|c|c|c|}
\hline Priority & $\begin{array}{l}\text { Time scale } \\
\text { for surgical } \\
\text { procedure } \\
\text { to be } \\
\text { performed }\end{array}$ & $\begin{array}{l}\text { Initial cleft operation } \\
\text { prioritisation July } 2020\end{array}$ & $\begin{array}{l}\text { Amendment to cleft prioritisation } \\
\text { February } 2021\end{array}$ \\
\hline $1 a$ & $\begin{array}{l}\text { Less than } \\
24 \text { hours }\end{array}$ & Nil & Nil \\
\hline $1 b$ & $\begin{array}{l}\text { Less than } \\
72 \text { hours }\end{array}$ & Nil & Nil \\
\hline 2 & $\begin{array}{l}\text { Less than } 1 \\
\text { month }\end{array}$ & Nil & $\begin{array}{l}\text { Primary cleft palate repair (child } \\
\text { breaching } 13 \text { months of age), } \\
\text { Secondary speech surgery (child } \\
\text { breaching } 5 \text { years of age) }\end{array}$ \\
\hline 3 & $\begin{array}{l}\text { Less than } 3 \\
\text { months }\end{array}$ & $\begin{array}{l}\text { Primary Palatoplasty, } \\
\text { Secondary Speech Surgery } \\
\text { Alveolar Bone Grafting }\end{array}$ & $\begin{array}{l}\text { Primary Palatoplasty (child less than } \\
12 \text { months of age), } \\
\text { Secondary Speech Surgery (child less } \\
\text { than } 5 \text { years of age) } \\
\text { Alveolar Bone Grafting (prior to } \\
\text { canine eruption) }\end{array}$ \\
\hline 4 & $\begin{array}{l}\text { More than } \\
3 \text { months }\end{array}$ & All other cleft operations & All other cleft operations \\
\hline
\end{tabular}


medRxiv preprint doi: https://doi.org/10.1101/2021.10.14.21265004; this version posted October 19, 2021. The copyright holder for this preprint (which was not certified by peer review) is the author/funder, who has granted medRxiv a license to display the preprint in

All rights reserved. No reuse allowed without permission.

\section{References}

Botticelli S, Küseler A, Mølsted K, Ovsenik M, Nørholt SE, Dalstra M, Cattaneo PM, Pedersen TK. Palatal morphology in unilateral cleft lip and palate patients: Association with infant cleft dimensions and timing of hard palate repair. Orthod Craniofac Res. 2019;22(4):270-280.

Chapman, KL, Hardin-Jones MA, Goldstein JA, Halter KA, Havlik RJ, Schulte J. Timing of palatal surgery and speech outcome. Cleft Palate Craniofac J. 2008;45(3):297-308.

CRANE. Crane Database Annual Report 2020. Available at: https://www.cranedatabase.org.uk/reports/?filter date=2020. Accessed October 14, 2021.

Dorf DS, Curtin JW. Early cleft palate repair and speech outcome. Plast Reconstr Surg. 1982; 70(1):74-81.

Follmar KE, Yuan N, Pendleton CS, Dorafshar AH, Kolk CV, Redett RJ. Velopharyngeal Insufficiency Rates After Delayed Cleft Palate Repair. Ann Plast Surg. 2015;75(3):302305.

Friede H. Maxillary Growth Controversies after Two-Stage Palatal Repair with Delayed Hard Palate Closure in Unilateral Cleft Lip and Palate Patients: Perspectives from Literature and Personal Experience. Cleft Palate Craniofac J. 2007;44(2):129-136.

Hardin-Jones MA, Jones DL. Speech Production of Preschoolers with Cleft Palate. Cleft Palate Craniofac J. 2005;42(1):7-13.

Heliövaara A, Küseler A, Skaare P, Shaw W, Mølsted K, Karsten A, Brinck E, Rizell S, Marcusson A, Sæle P, Hurmerinta K, Rønning E, Najar Chalien M, Bellardie H, Mooney J, Eyres $P$, Semb G. Scandcleft randomised trials of primary surgery for unilateral cleft lip and palate: 6. Dental arch relationships in 5 year-olds. J Plast Surg Hand Surg. 2017;51(1):52-57.

Kara M, Calis M, Kara I, Incebay O, Kulak Kayikci ME, Gunaydin RO, Ozgur F. Does early cleft palate repair make difference? Comparative evaluation of the speech outcomes using objective parameters. J Craniomaxillofac Surg.2020;48(11):1057-1065.

Karsten A, Marcusson A, Hurmerinta K, Heliövaara A, Küseler A, Skaare P, Bellardie H, Rønning E, Shaw W, Mølsted K, Sæle P, Brinck E, Rizell S, Najal Chalier M, Eyres P, Semb G. Scandcleft randomised trials of primary surgery for unilateral cleft lip and palate: 7. Occlusion in 5 year-olds according to the Huddart and Bodenham index. J Plast Surg Hand Surg. 2017;51(1):58-63

Küseler A, Mølsted K, Marcusson A, Heliövaara A, Karsten A, Bellardie H, Sæle P, Brinck E, Skaare P, Rizell S, Chalien MN, Mooney J, Eyres P, Shaw W, Semb G. Scandcleft randomized trials of primary surgery for unilateral cleft lip and palate: maxillary growth at eight years of age. European Journal of Orthodontics. 2019;42(1):24-29.

Liao YF, Cole TJ, Mars M. (2006). Hard palate repair timing and facial growth in unilateral cleft lip and palate: A longitudinal study. Cleft Palate Craniofac J. 2006;43(5):547-556

Liao YF, Mars M. Hard Palate Repair Timing and Facial Growth in Cleft Lip and Palate: A Systematic Review. Cleft Palate Craniofac J. 2006;43(5):563-570.

Liao YF, Yang IY, Wang R, Yun C, Huang CS. Two-Stage Palate Repair with Delayed Hard Palate Closure Is Related to Favorable Maxillary Growth in Unilateral Cleft Lip and Palate. Plast Reconstr Surg.2010;125(5):1503-1510.

Lohmander A, Persson C, Willadsen E, Lundeborg I, Alaluusua S, Aukner R, Bau A, Boers M, Bowden M, Davies J, Emborg B, Havstam C, Hayden C, Henningsson G, Holmefjord A, 
medRxiv preprint doi: https://doi.org/10.1101/2021.10.14.21265004; this version posted October 19, 2021. The copyright holder for this preprint (which was not certified by peer review) is the author/funder, who has granted medRxiv a license to display the preprint in

All rights reserved. No reuse allowed without permission.

Hölttä E, Kisling-Møller M, Kjøll L, Lundberg M, McAleer E, Nyberg J, Paaso M, Pedersen NH, Rasmussen T, Raisaeter S, Anderson HS, Schops A, Tordal IB, Semb G. Scandcleft randomised trials of primary surgery for unilateral cleft lip and palate: 4 . Speech outcomes in 5-year-olds - velopharyngeal competency and hypernasality. J Plast Surg Hand Surg. 2017;51(1):27-37.

Marrinan EM, Labrie RA, Mulliken JB. Velopharyngeal Function in Nonsyndromic Cleft Palate: Relevance of Surgical Technique, Age at Repair, and Cleft Type. Cleft Palate Craniofac J. 1998;35(2):95-100.

Pasick CM, Shay PL, Stransky CA, Solot CB, Cohen MA, Jackson OA. Long term speech outcomes following late cleft palate repair using the modified Furlow technique. Int $\mathrm{J}$ Pediatr Otorhinolaryngol. 2014;78(12):2275-2280.

Pereira RMR, Siqueira N, Costa E, Vale DD, Alonso N. Unilateral cleft lip and palate surgical protocols and facial growth outcomes. J Craniofac Surg. 2018;29(6):1562-1568.

Peterson-Falzone SJ. The relationship between timing of cleft palate surgery and speech outcome: What have we learned., and where do we stand in the 1990s? Semin Orthod. 1996;2(3):185-191.

Rezaei P, Poorjavad M, Abdali H. Speech outcomes after palatal closure in 3-7-year-old children. Braz J Otorhinolaryngol. 2020;S1808-8964(20)30152-X.

Salgado KR, Wendt AR, Fernandes Fagundes NC, Maia LC, Normando D, Leão PB. Early or delayed palatoplasty in complete unilateral cleft lip and palate patients? A systematic review of the effects on maxillary growth. J Craniomaxillofac Surg. 2019;47(11):16901698.

Shaffer AD, Ford MD, Losee JE, Goldstein J, Costello BJ, Grunwaldt L, Jabbour N. The Association Between Age at Palatoplasty and Speech and Language Outcomes in Children With Cleft Palate: An Observational Chart Review Study. Cleft Palate Craniofac J. 2020;57(2):148-160.

Swanson JW, Mitchell BT, Cohen M, Solot C, Jackson O, Low D, Bartlett SP, Taylor JA. The Effect of Furlow Palatoplasty Timing on Speech Outcomes in Submucous Cleft Palate. Ann Plast Surg. 2017;79(2):156-161.

Willadsen E. Influence of Timing of Hard Palate Repair in a Two-Stage Procedure on Early Speech Development in Danish Children with Cleft Palate. Cleft Palate Craniofac J. 2012;49(5):574-595.

Willadsen E, Boers M, Schöps A, Kisling-Møller M, Nielsen JB, Jørgensen LD, Andersen M, Bolund $S$, Andersen HS. Influence of timing of delayed hard palate closure on articulation skills in 3-year-old Danish children with unilateral cleft lip and palate. Int J Lang Commun Disord. 2018;53(1):130-143.

Willadsen E, Lohmander A, Persson C, Lundeborg I, Alaluusua S, Aukner R, Bau A, Boers M, Bowden M, Davies J, Emborg B, Havstam C, Hayden C, Henningsson G, Holmefjord A, Hölttä E, Kisling-M øller M, Kjøll L, Lundberg M, McAleer E, Nyberg J, Paaso M, Pederson $\mathrm{NH}$, Rasmussen T, Reisaeter S, Anderson HS, Schops A, Tordal IB, Semb G. Scandcleft randomised trials of primary surgery for unilateral cleft lip and palate: 5 . Speech outcomes in 5-year-olds - consonant proficiency and errors. J Plast Surg Hand Surg. 2017;51(1):38-51.

Williams WN, Seagle MB, Pegoraro-Krook MI, Souza TV, Garla L, Silva ML, Machado Neto JS, Dutka JCR, Nackashi J, Boggs S, Shuster J, Moorhead J, Wharton W, Graciano MIG, Pimentel MC, Feniman M, Piazentin-Penna SHA, Kemker J, Zimmermann MC, BentoGoncalvez C, Borgo H, Marques IL, Martinelli AP, Jorge JC, Antonelli P, Neves JF, 
medRxiv preprint doi: https://doi.org/10.1101/2021.10.14.21265004; this version posted October 19, 2021. The copyright holder for this preprint (which was not certified by peer review) is the author/funder, who has granted medRxiv a license to display the preprint in All rights reserved. No reuse allowed without permission.

Whitaker ME. (2011). Prospective Clinical Trial Comparing Outcome Measures Between Furlow and von Langenbeck Palatoplasties for UCLP. Ann Plast Surg. 2011;66(2):154163.

Xu X, Zheng Q, Lu D, Huang N, Li J, Li S, Wang Y, Shi B. Timing of palate repair affecting growth in complete unilateral cleft lip and palate. J Craniomaxillofac Surg. 2012:40(8):e358-362.

Yang Y, Li Y, Wu Y, Gu Y, Yin H, Long H, Shi B, Zheng Q. Velopharyngeal Function of Patients With Cleft Palate After Primary Palatoplasty. J Craniofac Surg. 2013;24(3):923-928. 